Kazuhiro Tsukamoto $\cdot$ Satoshi Inoue $\cdot$ Takayuki Hosoi

Hajime Orimo $\cdot$ Mitsuru Emi

\title{
Isolation and radiation hybrid mapping of dinucleotide repeat polymorphism at the human estrogen receptor $\beta$ locus
}

\begin{abstract}
A gene for a second type of human estrogen receptor, the estrogen receptor $\beta$ (ESR $\beta$ ), was recently identified. We isolated a polymorphic dinucleotide CA repeat marker from a genomic clone containing the human estrogen receptor $\beta$ gene. High heterozygosity (0.93) makes this polymorphism a useful marker in the genetic study of disorders affecting female endocrine systems; calcium metabolism; and breast, uterine, and ovarian cancers.
\end{abstract}

Key words Estrogen receptor - CA repeat - Calcium metabolism $\cdot$ Breast cancer $\cdot$ Ovarian cancer

\section{Introduction}

A second type of estrogen receptor gene, the estrogen receptor $\beta$ gene, recently isolated by Mosselman et al. (1996), had $96 \%$ conserved amino acid residues in the DNA binding domain and $58 \%$ conserved residues in the ligandbinding domain when compared with the estrogen receptor. To understand the relationship between genetic variations at the $\operatorname{ESR} \beta$ locus and disorders affecting endocrine systems; calcium metabolism; and breast, uterine, and ovarian cancers (Nakamura 1996; Yanase 1997), we isolated and characterized a dinucleotide repeat polymorphism at this locus.

K. Tsukamoto $\cdot$ M. Emi $(\bowtie)$

Department of Molecular Biology, Institute of Gerontology, Nippon Medical School, 1-396 Kosugi-cho, Nakahara-ku, Kawasaki 211,

Japan

Tel. +81-44-733-5230; Fax +81-44-733-5192

e-mail:memi@nms.ac.jp

S. Inoue $\cdot$ T. Hosoi $\cdot$ H. Orimo

Department of Geriatrics, Faculty of Medicine, University of Tokyo,

Tokyo, Japan

\section{Source and isolation of $\mathrm{CA}$ repeat sequence}

A human genomic clone containing the ESR $\beta$ gene was identified from a P1-derived artificial chromosome (PAC) library by polymerase chain reaction (PCR) 3-dimensional screening using primer sequences derived from the $3^{\prime}$ portion of the gene. A fragment containing the CA repeat was identified by Southern blotting of PAC DNA digested by HaeIII, Sau3A, or RsaI with a (GT)20 probe and was subcloned and sequenced. An autoradiogram of the CA repeat sequence is shown in Fig. 1B. PCR primers were designed to flank this new repeat sequence for polymorphism analysis.

PCR primers

Forward (ERB, 4F) 5' -GGT AAA CCA TGG TCT GTA CC- 3'

Reverse (ERB, 5R) 5' -AAC AAA ATG TTG AAT

GAG TGG G- 3'

\section{PCR conditions}

PCR was performed with $20 \mathrm{ng}$ genomic DNA, $10 \mathrm{mM}$ TrisHCl ( $\mathrm{pH} 8.4$ ), $50 \mathrm{mM} \mathrm{KCl}, 1.5 \mathrm{mM} \mathrm{MgCl}_{2}, 0.01 \%$ of gelatin, $200 \mu \mathrm{M}$ dNTPs, $2.5 \mathrm{pmol}$ of a $\left[{ }^{32} \mathrm{P}\right]$ end-labeled forward primer and a nonlabeled reverse primer, and 0.25 units of $\mathrm{Taq}$ polymerase in a volume of $10 \mu \mathrm{l}$. Cycle conditions were $94^{\circ} \mathrm{C}$ for $4 \mathrm{~min}$, then 30 cycles of $94^{\circ} \mathrm{C}$ for $30 \mathrm{~s}, 65^{\circ} \mathrm{C}$ for $30 \mathrm{~s}$, and $72^{\circ} \mathrm{C}$ for $30 \mathrm{~s}$, with a final extension step of $5 \mathrm{~min}$ at $72^{\circ} \mathrm{C}$ in a Gene Amp PCR9600 System (Perkin Elmer Cetus, Norwalk, CT, USA) (Nakura et al. 1994). PCR products were electrophoresed in $0.3-\mathrm{mm}$-thick denaturing $6 \%$ polyacrylamide gels containing $36 \%$ formamide and $8 \mathrm{M}$ urea, at $2000 \mathrm{~V}$ for 2-4 h. Gels were transferred to filter papers, dried at $80^{\circ} \mathrm{C}$, and autoradiographed. The sizes of alleles were determined by comparison with a sequencing ladder of a control plasmid. 
A

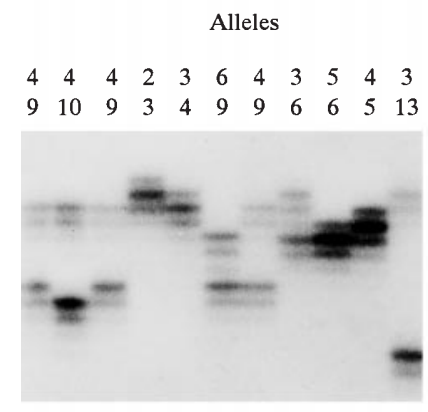

B

G A T C

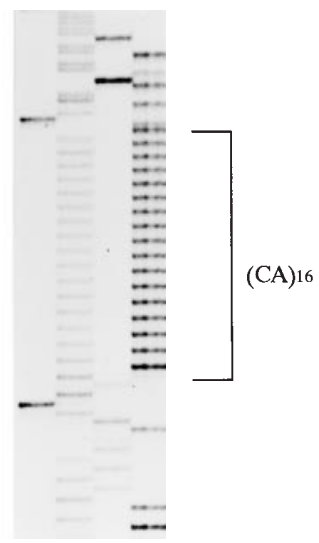

Fig. 1 A Autoradiogram showing a polymorphic CA repeat at the estrogen receptor $\beta(E S R \beta)$ locus in 11 unrelated individuals. B Nucleotide sequence of the CA repeat at the ESR $\beta$ locus and the flanking regions

Table 1 Size and frequency of the alleles of the CA repeat polymorphism in the estrogen receptor $\beta(E S R \beta)$ locus

\begin{tabular}{lll}
\hline Allele & Size $(\mathrm{bp})$ & Frequency \\
\hline A1 & 194 & 0.01 \\
A2 & 192 & 0.01 \\
A3 & 190 & 0.01 \\
A4 & 188 & 0.02 \\
A5 & 186 & 0.06 \\
A6 & 184 & 0.07 \\
A7 & 182 & 0.06 \\
A8 & 180 & 0.06 \\
A9 & 178 & 0.08 \\
A10 & 176 & 0.07 \\
A11 & 174 & 0.03 \\
A12 & 172 & 0.04 \\
A13 & 170 & 0.13 \\
A14 & 168 & 0.13 \\
A15 & 166 & 0.18 \\
A16 & 164 & 0.06 \\
A17 & 162 & 0.01 \\
A18 & 160 & 0.01 \\
\hline
\end{tabular}

\section{Polymorphism and allele frequency}

Eighteen alleles were detected in 192 chromosomes of unrelated Japanese individuals. A representative autoradiogram of the CA repeat polymorphism is shown in Fig. 1A. The observed heterozygosity was 0.93 . The size and frequency of the 18 alleles are shown in Table 1.

Mendelian inheritance. Codominant inheritance was observed in two three-generation families.

Chromosomal localization. The human ESR $\beta$ gene has been assigned to human chromosome 14q (Mosselman et al. 1996).

Radiation hybrid mapping. The newly isolated CA repeat at the ESR $\beta$ locus was mapped to $14 \mathrm{q}$ using the G3 RH mapping panel of 83 hybrid cell lines of the Stanford Human Genome Center (SHGC) (Boehnke et al. 1991), by linkage to a marker SHGC-11003 with a logarithm of differences (LOD) score of $>100$.

Acknowledgments This work was supported by a research grant for osteoporosis from the Ministry of Health and Welfare of Japan and the Novartis foundation for gerontological research.

\section{References}

Boehnke M, Lang K, Cox DR (1991) Statistical methods for multipoint radiation mapping. Am J Hum Genet 49:1174-1188

Mosselman S, Polman J, Dijkema R (1996) ER-beta: identification and characterization of a novel human estrogen receptor. FEBS Lett 392: $49-53$

Nakura J, Miki T, Ye L, Mitsuda N, Ogihara T, Ohta T, Jinno Y, Niikawa N, Takahashi A, Ishini Y (1994) Six dinucleotide repeat polymorphisms on chromosome 7. Jpn J Hum Genet 39:447449

Nakamura Y (1996) Application of DNA markers to clinical genetics. Jpn J Hum Genet 41:1-14

Yanase T (1997) Human genetics: past, present, and future. Jpn J Hum Genet 42:265-316 